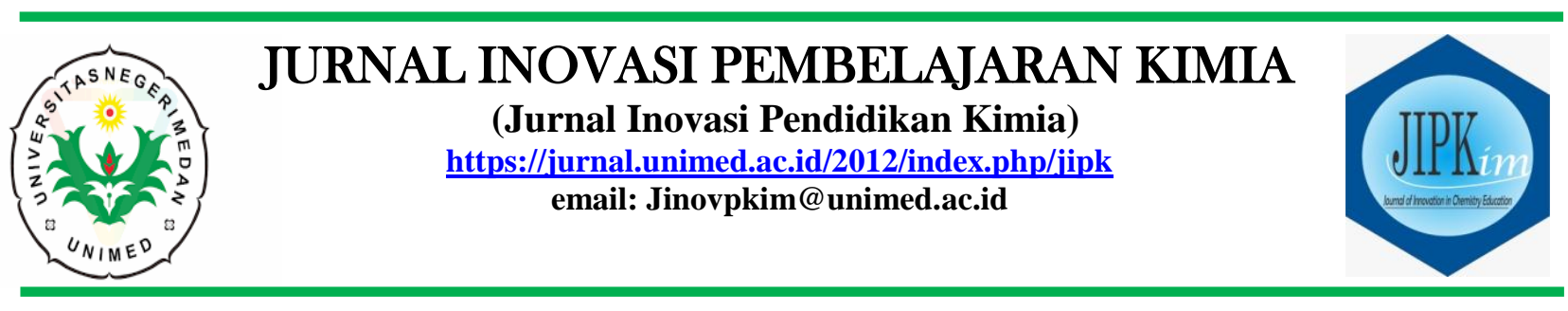

$\begin{array}{ll}\text { Masuk } & : \text { 6 Juli } 2021 \\ \text { Revisi } & : 4 \text { Oktober } 2021 \\ \text { Diterima } & : \text { 19 Oktober } 2021 \\ \text { Diterbitkan } & : \text { 30 Oktober } 2021 \\ \text { Halaman } & : 123-135\end{array}$

\title{
Pengembangan Uji Instrumen Tiga Tingkat Dengan CRI Untuk Mendeteksi Miskonsepsi Dalam Pembelajaran Reaksi Redoks
}

\author{
Fatayatul Hasniyah $^{1 *}$, Zainuddin Muchtar ${ }^{1}$ \\ ${ }^{1}$ Program Studi Pendidikan Kimia, Universitas Negeri Medan, Medan \\ *Alamat Korespondensi: fatayatul27@gmail.com
}

\begin{abstract}
Research has been carried out to develop a Three Tier Instrument Test with Certainty of Response Index (CRI) with the aims to find out (1) analysis of teaching learning chemistry, (2) the eligibility categories in terms of expert validation, (3) the percentage of misconceptions in each sub-concepts of redox reaction, and (4) the causes of students' misconceptions about redox reaction material. The instrument is prepared with 10 items validated contains each sub-concepts. Research results show that: (1) teaching learning chemistry using curriculum 2013, various student textbooks and methods so research develop many aspects of question instruments that needed in research by interviewing the teacher of each schools, (2) the test instrument has very decent criteria with the assessment of material, language, and construction aspect, (3) the lowest percentages of students' misconception in redox reaction's sub-concept is oxidizing and reducing agent in reaction (54.09\%) and the highest percentages is in sub-concept of autoredox concept (69.98\%) with all categories of misconceptions are enough, (4) the causes of students' misconceptions in learning redox reaction found in the material, learning source, teachers aspect. It because students were taught by different teacher, different method, and different source in learning redox reaction.
\end{abstract}

Keywords: Misconceptions, Three-Tier Instrument Test, Certainty Response Index (CRI), Redox Reaction

\section{PENDAHULUAN}

Kimia merupakan salah satu mata pelajaran IPA yang mempelajari banyak konsep-konsep abstrak dan beberapa diantaranya mencoba menjelaskan fenomena kimia dalam kehidupan sehari-hari. Tujuan utama pelajaran kimia adalah untuk memperkenalkan siswa dengan fenomena sehari-hari dan membantu mereka untuk memahami apa yang terjadi di alam: semua pedoman untuk pendidikan kimia, buku sekolah dan sebagian besar kurikulum harus bertujuan untuk mencapai tujuan ini. Selain itu, prinsip-prinsip psikologi perlu menawarkan fenomena agar siswa dapat mengamati sendiri. Berdasarkan pengamatan tersebut, mereka akan menemukan penjelasan awal dan akan mengembangkan struktur kognitif mereka. Berdasarkan Hazari (2019), pengalaman memulai pembelajaran dalam kimia, calon guru seringkali tidak jelas penyampaiannya tentang prakonsepsi atau dapat membuat miskonsepsi mereka sendiri. 
Menurut pendekatan pembelajaran ini, siswa menghasilkan makna mereka sendiri berdasarkan latar belakang, sikap, kemampuan, pengalaman, dll., sebelum, selama, dan setelah pengajaran.

Reaksi redoks adalah materi kimia yang mempelajari tentang zat pereduksi (zat yang melepaskan atau menyumbangkan elektron, atau mengalami oksidasi; yang bilangan oksidasinya meningkat) dan zat pengoksidasi (zat yang memperoleh atau menerima elektron atau mengalami reduksi; atau yang bilangan oksidasinya menurun) (NARICT, 2010). Seperti dalam sejarah perkembangan konsep redoks, definisi transfer oksigen dalam topik awal berubah menjadi transfer elektron dalam topik lanjutan setelah subjek struktur atom dibahas. Konsep pokok materi redoks mengalami perubahan makna hingga empat kali, yaitu redoks berdasarkan transfer oksigen, redoks berdasarkan transfer hidrogen, redoks berdasarkan transfer elektron, dan redoks berdasarkan perubahan bilangan oksidasi. Perubahan makna konsep dan penyelesaian soal redoks yang membutuhkan banyak tahapan membuat siswa kesulitan menyelesaikan soal reaksi redoks (Anshori, dkk., 2016).

Banyak penelitian pengembangan tentang instrumen yang digunakan untuk mendeteksi miskonsepsi siswa. Ada tiga cara untuk mendeteksi miskonsepsi: (1) pilihan ganda dasar; (2) pilihan ganda dua tingkat dan; (3) pilihan ganda tiga tingkat (Masykuri dkk., 2019). Salah satu teknik yang dapat digunakan untuk mengidentifikasi letak miskonsepsi siswa adalah instrumen pilihan ganda tiga tingkat. Teknik pilihan ganda tiga tingkat (three-tier) merupakan gabungan dari teknik two-tier dan teknik Certainty of Response Index (CRI) yang mengukur tingkat kepercayaan siswa terhadap jawaban mereka pada dua tier pertama.

Beberapa penelitian sebelumnya untuk mengetahui miskonsepsi reaksi redoks telah dilakukan oleh Wulandari dkk., 2019; Masykuri dkk., 2019; Nurrohmah dkk., 2018; dan Nurlela dkk., 2017 dengan metode dan hasil yang berbeda satu sama lain. Wulandari dkk., 2019 membahas miskonsepsi terbesar pada sub indikator aplikasi dan persamaan reaksi redoks sebesar 46,89\%. Masykuri dkk., 2019 hanya membahas miskonsepsi pada sub indikator konsep redoks berdasarkan serah terima oksigen, kenaikan dan penurunan bilangan oksidasi, dan konsep reduktor dan oksidator. Nurrohmah dkk., 2018 membahas dan mendapatkan miskonsepsi siswa yang menggunakan sistem CBT dengan software RDT pada materi reaksi redoks. Nurlela dkk., 2017 membahas miskonsepsi menggunakan instrument tes dua tingkat dengan Certain Response Index (CRI) atau tingkat kepercayaan siswa terhadap jawaban.

Berdasarkan uraian tersebut, maka peneliti perlu melakukan penelitian yang bertujuan untuk mengidentifikasi miskonsepsi siswa dengan menggunakan pilihan ganda tiga tingkat pada materi konsep redoks di kelas $X$. Peneliti juga menentukan hasil kategori kelayakan instrumen tes objektif dan penyebab miskonsepsi untuk mendeteksi miskonsepsi reaksi redoks kelas $\mathrm{X}$ berdasarkan instrumen tes objektif pilihan ganda tiga tingkat dengan Certainty of Response Index (CRI).

\section{KAJIAN LITERATUR}

\section{Konsep dan Prakonsepsi}

Sebelum siswa mempelajari konsep kimia, mereka membawa suatu konsep yang disebut prakonsepsi. Biasanya siswa punya persepsi sendiri sebelum menerima pembelajaran, ketika berinteraksi dengan lingkungan, mereka membawa banyak pengalaman atau ide yang sudah ada sebelumnya (Pinker, 2003). Ide-ide ini disebut pengetahuan awal, prasangka atau konsep alternatif yang akan menjadi membangun pengetahuan mereka selanjutnya (Gani dkk., 2017). Konsep adopsi dan pengembangan otonom tidak selalu sama dengan konsep sebenarnya yang diajukan oleh ahli kimia (Dhindsa \& Treaguest, 2009). Ketika mereka mengikuti proses pembelajaran dan menerima konsep baru, mereka akan berusaha menyelaraskan konsep 
baru dengan konsep yang sudah ada. Dalam proses penyesuaian ini, beberapa kemungkinan dapat terjadi, antara lain:

1. Guru salah menyampaikan konsep, tetapi siswa merekonstruksi konsep dengan benar;

2. Guru menyampaikan konsep dengan benar, tetapi siswa tidak merekonstruksi konsep yang benar. Struktur sebenarnya adalah konsep yang salah;

3. Guru menyampaikan konsep dengan benar, sedangkan siswa merekonstruksi konsep yang salah.

Dalam kasus pertama (1) dan kedua (2), miskonsepsi disebabkan oleh pihak sekolah dan siswa itu sendiri. Jika guru tidak segera menemukannya, maka miskonsepsi akan berlanjut dan berakibat fatal karena akan menimbulkan pemahaman yang salah terhadap keseluruhan konsep kimia. Di dalam situasi ketiga (3), siswa sudah memiliki ide-ide konstruktivis, dan mereka diharapkan terjadi dalam studi mereka (Salirawati, 2017).

\section{Miskonsepsi}

Miskonsepsi adalah ide yang dibentuk oleh siswa berdasarkan pengalaman yang tidak sesuai dengan konsep ilmiah. Adanya miskonsepsi ini akan mempengaruhi perkembangan pemahaman siswa dan menghambat proses belajar siswa selanjutnya karena miskonsepsi akan menimbulkan pengetahuan baru yang dimiliki siswa yang tidak dapat dikaitkan dengan pengetahuan kognitif, sehingga pemahaman konsep siswa menjadi lemah. Miskonsepsi siswa dapat disebabkan oleh berbagai faktor internal dan eksternal. Faktor internal yang mempengaruhi terbentuknya miskonsepsi siswa antara lain prasangka, pemikiran asosiatif, pemikiran humanistik, intuisi yang salah, perkembangan tahap kognitif, penalaran yang tidak lengkap/salah, kemampuan, dan minat belajar, sedangkan faktor eksternal meliputi pengalaman seharihari, guru, buku ajar, dan penggunaan bahasa (Siswaningsih dkk., 2020).

\section{Penyebab Miskonsepsi}

1. Buku/bahan referensi

Buku ini mungkin tidak memiliki cukup referensi atau bukti. Buku dapat memuat konten yang ambigu, bahasa yang meragukan, tidak memiliki contoh yang lengkap atau memadai untuk memahami konten atau konsep tertentu.

2. Bahasa guru

Bahasa adalah alat komunikasi yang ampuh. Bahasa komunikatif guru dapat mempengaruhi miskonsepsi dalam pembelajaran siswa dan konsep ilmiah baru dapat muncul.

3. Keluarga

Temperamen ilmiah anggota keluarga terutama yang berusia lanjut juga akan mempengaruhi pemahaman siswa terhadap konsep-konsep ilmiah. Peran yang diberikan kepada anggota keluarga dapat menghambat pemikiran ilmiah dan pembentukan konsep.

4. Kelompok sebaya

Kelompok sebaya lebih berpengaruh dalam bentuk pembelajaran informal siswa, terutama teman sebaya di sekolah, seperti pemikiran abstrak, aturan, nilai, dan komitmen siswa.

5. Keyakinan budaya

Latar belakang pribadi keluarga, keyakinan dan agama, komunitas, upacara, tradisi, masyarakat tempat siswa tinggal juga penting dalam pembentukan konsep ilmiah siswa.

6. Media

Media adalah alat yang paling ampuh untuk membentuk atau mengembangkan cara berpikir pribadi. Saluran televise sebagai salah satu contoh media yang menyebarkan keyakinan yang salah ataupun tidak memiliki dasar ilmiah dapat menyebabkan siswa salah paham.

7. Keyakinan pribadi siswa

Salah satu sumber miskonsepsi siswa seperti keyakinan pribadi siswa tentang sekolah, media, masyarakat, orang tua, diskusi kelompok sebaya, pengalaman, dll. juga mendukung terciptanya miskonsepsi (Patil dkk., 2019). 


\section{Identifikasi Miskonsepsi}

1. Tes asosiasi kata

Asosiasi kata adalah salah satu metode tertua dalam studi struktur kognitif dan telah banyak digunakan.

2. Tes pilihan ganda

Soal pilihan ganda sangat berguna untuk penilaian langsung dan dapat diterapkan pada sejumlah besar siswa, dan telah digunakan untuk menentukan konsep siswa.

3. Tes diagnostik dua tingkat dan tiga tingkat

Tes pilihan ganda dua tingkat digunakan sebagai alat diagnostik, di mana tingkat pertama mencakup pertanyaan konten pilihan ganda dan tingkat kedua mencakup rangkaian alasan pilihan ganda untuk jawaban siswa tingkat pertama. Tingkat ketiga digunakan untuk memastikan keyakinan siswa memilih jawaban yang benar.

4. Gambar

Sacit Kose (2008) menggunakan gambar sebagai alat untuk mengetahui miskonsepsi siswa sekolah menengah tentang biologi. Dalam hal ini, jika anak menggambar binatang yang terangsang, guru dapat bertanya kepada mereka mengapa dia melukisnya.

5. Teks perubahan konsep

Pada awalnya, siswa akan salah paham tentang subjek, dan kemudian mereka menjelaskan secara ilmiah mengapa pemahaman ini salah. Dalam teks perubahan konsep, siswa diberi pertanyaan langkah demi langkah untuk mengaktifkan pemahaman mereka tentang subjek.

6. Daftar konsep
Daftar konsep adalah desain instrumen yang digunakan untuk menguji pilihan ganda penelitian tingkat pemahaman konsep siswa. Menurut konsep kunci subjek, setiap pertanyaan atau item memiliki jawaban yang benar dan jawaban yang salah. Penggunaan daftar konsep yang paling umum adalah untuk mendiagnosis miskonsepsi pengganti.

7. Tes diagnostik online

Ini adalah desain sederhana untuk diagnosis miskonsepsi siswa berbasis komputer. Tes konsep pra-tetap dapat menunjukkan di mana siswa mendapatkan kesalahan pada tautan, strategi, atau pengetahuan.

8. Kuesioner terbuka

Kuesioner terbuka memberikan waktu untuk berpikir dan menjelaskan ide-ide siswa sendiri, tetapi secara umum, sulit untuk mengevaluasi hasilnya (Patil dkk., 2019).

\section{METODE}

\section{Metode Penelitian}

Penelitian ini dilakukan di empat SMA sebagai populasi sampel, yaitu SMA Dharmawangsa Medan, SMA Negeri 1 Percut Sei Tuan, MAN 1 Medan, dan MAS PAB 2 Helvetia pada semester genap tahun pelajaran 2020/2021. Sampel siswa dipilih hanya satu kelas di setiap sekolah. Produk yang dikembangkan dalam penelitian ini adalah instrumen tes objektif berbasis pilihan ganda tiga tingkat untuk mengidentifikasi miskonsepsi siswa pada materi reaksi redoks menggunakan metode Research and Development (R\&D) dengan model ADDIE. Prosedur pengembangan digambarkan dalam bagan yang dijelaskan pada Gambar 1:

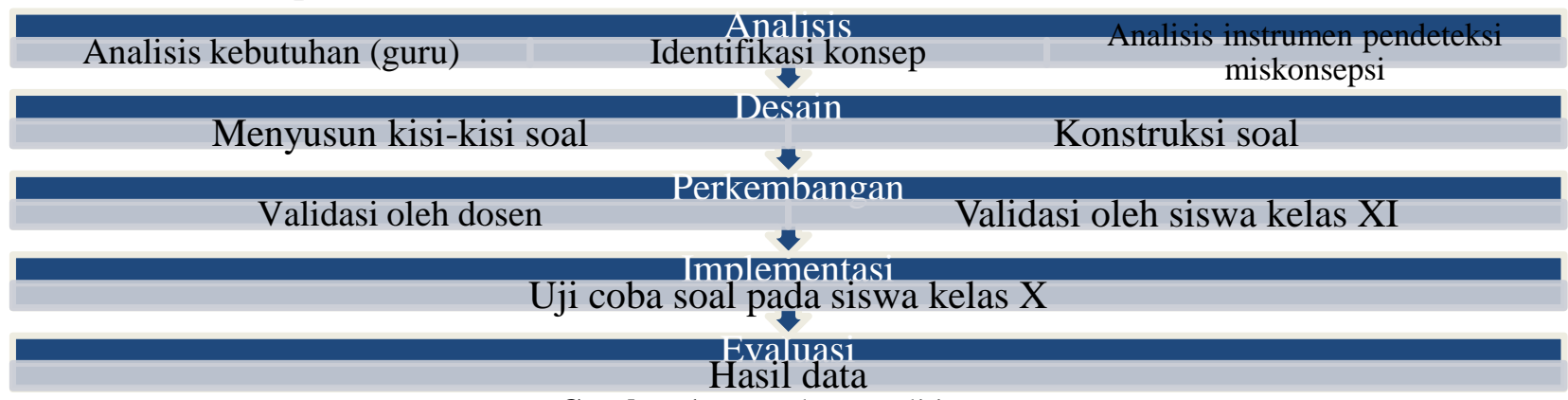

Gambar 1. Prosedur Penelitian 


\section{Instrumen Penelitian}

Untuk instrumen penelitian, peneliti membuat 4 (empat) instrumen untuk mendukung data. Instrumen penelitian adalah alat yang digunakan peneliti untuk mengumpulkan data penelitian agar peneliti dapat bekerja dengan mudah dan mendapatkan hasil yang lebih baik (Yuberti \& Siregar, 2017). Instrument yang digunakan dalam penelitian ini sebagai berikut:

1. Wawancara

Wawancara dilakukan kepada guru-guru sebelum melakukan penelitian guna mengetahui kegiatan belajar mengajar pada masing-masing sekolah.

2. Kuesioner Validasi

Uji validitas instrumen oleh dosen sebelum melakukan penelitian kepada siswa (sampel). Setelah divalidasi, instrumen tes digunakan pada siswa kelas XI untuk mengetahui uji validitas, reliabilitas, tingkat kesukaran, daya diskriminasi, dan distruktor oleh siswa yang telah mempelajari reaksi redoks di kelas.

3. Uji Instrumen Tiga Tingkat dengan Indeks Kepastian Respon (CRI)

Instrumen ini digunakan untuk mengetahui hasil persentase miskonsepsi yang dilakukan siswa. Instrumen diberikan setelah pembelajaran materi reaksi redoks oleh guru. Instrumen tes hanya mengukur aspek kognitif siswa yang meliputi $\mathrm{C} 1$ (pengetahuan), C2 (pemahaman), C3 (aplikasi), dan $\mathrm{C} 4$ (analisis) dalam pembelajaran materi reaksi redoks.

4. Kuisioner Siswa

Untuk mendeteksi penyebab miskonsepsi siswa, kuesioner diberikan setelah dilakukan pengerjaan tes instrument soal tiga tingkat.

\section{Analisis Penilaian Butir Soal Untuk Mengukur Miskonsepsi Siswa}

Analisis data miskonsepsi digunakan untuk mendapatkan gambaran miskonsepsi siswa dalam pembelajaran reaksi redoks dan mengelompokkan

data berdasarkan kemampuan dan pemahaman siswa, kemudian merekapitulasi siswa yang mendapatkan jawaban benar/Scientifically Correct (SC), sebagian benar/Partically Correct (PC), miskonsepsi/Specific Misconception (SM), dan tidak mengerti/No Understanding (NU) berdasarkan Nurlela (2017) sebagai berikut:

Tabel 1. Format Persentase Miskonsepsi

\begin{tabular}{lllll}
\hline Sub-Konsep & \multicolumn{4}{c}{ Persentase } \\
\cline { 2 - 5 } & SC & PC & SM & NU \\
& & & & \\
\hline
\end{tabular}

Untuk metode perhitungan persentase miskonsepsi berdasarkan Mahardika (2014) sebagai berikut:

$$
P=\frac{f}{N} \times 100 \%
$$

Informasi:

$\mathrm{P}=$ Persentase miskonsepsi

$\mathrm{F}=$ Frekuensi yang dicari persentasenya

$\mathrm{N}=$ Banyaknya siswa

Sampel siswa akan dikelompokkan ke dalam empat kategori berbeda yang membantu untuk mengklasifikasikan penjelasan yang dapat diterima dan tidak dapat diterima secara ilmiah, dan kemudian dikelompokkan menurut kriteria berikut:

Tabel 2. Pengelompokan Analisis Data

\begin{tabular}{|c|c|c|c|}
\hline Sedang & $\mathrm{k}$ & eria & tingkat \\
\hline Level 1 & Level 2 & Level 3 (CRI) & Keterangan \\
\hline Benar & Benar & Yakin & Benar (SC) \\
\hline Benar & Salah & Yakin & $\begin{array}{l}\text { Miskonsepsi } \\
\text { (SM) }\end{array}$ \\
\hline Salah & Benar & Yakin & $\begin{array}{l}\text { Miskonsepsi } \\
\text { (SM) }\end{array}$ \\
\hline Salah & Salah & Yakin & $\begin{array}{l}\text { Miskonsepsi } \\
\text { (SM) }\end{array}$ \\
\hline Benar & Benar & Tidak Yakin & $\begin{array}{l}\text { Sebagian Benar } \\
\text { (PC) }\end{array}$ \\
\hline Benar & Salah & Tidak Yakin & $\begin{array}{l}\text { Sebagian Benar } \\
\text { (PC) }\end{array}$ \\
\hline Salah & Benar & Tidak Yakin & $\begin{array}{l}\text { Sebagian Benar } \\
\text { (PC) }\end{array}$ \\
\hline Salah & Salah & Tidak Yakin & $\begin{array}{l}\text { Tidak Mengerti } \\
\text { (NU) }\end{array}$ \\
\hline
\end{tabular}


kepercayaan diri siswa dalam menjawab tes atau CRI (Certainty of Response Index) disertai dengan soal tes objektif, yaitu sebagai berikut:

Tabel 3. Pengelompokan Analisis Data CRI

\begin{tabular}{ccc}
\hline CRI & Kriteria & $\begin{array}{c}\text { Tingkat } \\
\text { Percaya Diri }\end{array}$ \\
\hline $\mathbf{0}$ & Hanya menebak & \\
$\mathbf{1}$ & Sangat tidak percaya diri & Tidak Yakin \\
$\mathbf{2}$ & Tidak percaya diri & \\
$\mathbf{3}$ & Percaya diri & \\
$\mathbf{4}$ & Sangat percaya diri & Yakin \\
$\mathbf{5}$ & Benar-benar percaya diri & \\
\hline
\end{tabular}

Langkah selanjutnya adalah menginterpretasikan persentase miskonsepsi seperti pada tabel 4 .

Tabel 4. Kriteria Persentase Miskonsepsi

\begin{tabular}{cc}
\hline Nilai P & Informasi \\
\hline $\mathbf{0 \%} \geq \mathbf{3 0 \%}$ & Rendah \\
$\mathbf{3 1 \%} \geq \mathbf{6 0 \%}$ & Sedang \\
$\mathbf{6 1 \%} \geq \mathbf{1 0 0 \%}$ & Tinggi \\
\hline
\end{tabular}

\section{Analisis Penilaian Kuesioner Respon Siswa}

Angket respon siswa digunakan untuk mengetahui penyebab miskonsepsi siswa pada materi reaksi redoks setelah siswa melakukan Instrumen Tiga Tingkat dengan Indeks Kepastian Respon (CRI). Rekapitulasi angket respon siswa berdasarkan Skala Guttman sebagai berikut:

Tabel 5. Format Persentase Kuesioner Respon Siswa

\begin{tabular}{cccc}
\hline Aspek & Sub- \\
\cline { 3 - 3 } & Konsep & & \multicolumn{2}{c}{ Persentase } \\
\hline
\end{tabular}

Masing-masing aspek angket dianalisis untuk mengetahui rata-rata indikator penyebab miskonsepsi siswa dengan rumus yang sama dengan metode perhitungan persentase miskonsepsi.

\section{HASIL DAN PEMBAHASAN}

\section{Deskripsi Hasil Penelitian}

Produk yang dikembangkan dalam penelitian ini adalah instrumen tes objektif berbasis pilihan ganda tiga tingkat untuk mengidentifikasi miskonsepsi siswa pada materi reaksi redoks menggunakan metode Research and Development dengan model ADDIE. Hasil dari setiap tahapan dijelaskan sebagai berikut:

1. Analisis

Tahap awal dalam penelitian ini adalah analisis proses pembelajaran kimia di kelas X masing-masing sekolah. Hasil analisis proses pembelajaran terangkum dalam hasil angket wawancara dengan guru sebagai berikut: kebutuhan kurikulum, buku ajar siswa, dan metode pengajaran.

2. Desain

Tahap kedua dalam penelitian ini adalah merancang dan menyusun kisi-kisi soal melalui Uji Instrumen Tiga Tingkat dengan Indeks Kepastian Respons (CRI) materi reaksi redoks berdasarkan kebutuhan silabus dan kurikulum. Kemudian dilajutkan menyusun soal berdasarkan kisi-kisi soal. Soal dikerjakan dengan 30 (tiga puluh) butir soal sebelum divalidasi. Data yang diperoleh diuraikan sebagai berikut: indikator, kisi-kisi soal, instruksi kerja soal, Tes Instrumen Tiga Tingkat dengan Indeks Kepastian Respon (CRI), pedoman penilaian, dan angket penyebab miskonsepsi siswa.

3. Perkembangan

Tahap ketiga dalam penelitian ini adalah pengembangan validasi produk instrumen tes oleh ahli materi, isi, dan bahasa dari dosen yang ahli di bidangnya, kemudian hasil validasi tersebut diujicobakan pada siswa kelas XI yang telah mempelajari reaksi redoks pada semester sebelumnya untuk menentukan validitas, reliabilitas, tingkat kesukaran, daya pembeda, dan pengecoh.

4. Implementasi

Tahap keempat dalam penelitian ini adalah implementasi yang dilakukan untuk mengukur miskonsepsi pada siswa kelas X. Tahap implementasi produk instrumen tes objektif untuk mendeteksi 
miskonsepsi siswa pada materi reaksi redoks dilakukan secara dalam jaringan melalui google form dan luar jaringan/tatap muka dengan durasi waktu pengerjaan soal selama 45 menit. Produk akhir diujicobakan kepada siswa dengan 10 (sepuluh) butir soal setelah divalidasi.

\section{Evaluasi}

Langkah terakhir dari penelitian ini adalah melakukan dan mengevaluasi analisis data untuk mengetahui nilai respon siswa terhadap seluruh instrumen yang dikembangkan. Pada tahap ini juga dilakukan penilaian terhadap hasil angket penyebab miskonsepsi siswa dalam pembelajaran reaksi redoks di kelasnya masing-masing.

\section{Hasil Uji Validitas Instrumen Penelitian}

Dalam hasil uji instrumen 30 (tiga puluh) soal sebelum validasi didapatkan ratarata kelayakan materi $100 \%$ dan bernilai valid, rata-rata kelayakan konstruksi 91,66\% dan bernilai valid, serta rata-rata kelayakan bahasa yang digunakan adalah $100 \%$ dan bernilai valid. Kesimpulan dari validasi dosen terhadap Uji Instrumen Tiga Tingkat dengan Indeks Kepastian Respon (CRI) pada materi redoks adalah layak digunakan dengan revisi jika ada soal yang dianggap tidak sesuai. Hasil validasi dosen ini dilanjutkan sebagai acuan dalam proses validasi soal oleh siswa kelas XI di MAN 1 Medan.

1. Uji Validitas

Butir soal dinyatakan valid jika $r_{x y}$ hitung $>r_{x y}$ tabel $(0,334)$. Dalam uji validitas, diperoleh 20 (dua puluh) dari 30 (tiga puluh) butir soal memenuhi kriteria valid.

2. Uji Reliabilitas

Jika instrumen tersebut sesuai dengan hasil pengukuran, maka instrumen tersebut dapat dikatakan reliabel, sehingga dapat dipercaya. Butir soal dikatakan reliabel jika $r_{x y}$ hitung $>r_{x y}$ tabel (0,334). Pada penelitian ini $r_{x y}$ hitung $=0,891$, sehingga dapat disimpulkan bahwa butir soal instrumen reliabel dengan interpretasi uji reliabilitas tinggi.
3. Uji Tingkat Kesulitan

Uji tingkat kesulitas memenuhi syarat jika $0.20>\mathrm{P} \geq 0.80$. Dalam uji ini, diperoleh 19 (sembilan belas) butir soal memenuhi kriteria tingkat kesukaran butir soal yaitu kriteria baik.

4. Uji Daya Pembeda

Uji daya pembeda memenuhi syarat jika $0.20>\mathrm{P} \geq 0.80$. Dalam uji ini, diperoleh 19 (sembilan belas) butir soal memenuhi kriteria daya pembeda butir soal yaitu kriteria baik.

5. Pengecoh

Hasil terbaik dari pengecoh ketika minimal 5\% siswa telah memilih opsi pengecoh, $\mathrm{BA} \leq \mathrm{BB}$, dan tidak lebih dari $5 \%$ siswa tidak menjawab soal. Terdapat 15 (lima belas) pertanyaan yang memenuhi syarat dan dapat digunakan untuk instrumen penelitian. Diantara 15 (lima belas) item pertanyaan, peneliti menggunakan 10 (sepuluh) item pertanyaan untuk melakukan penelitian untuk mendapatkan hasil miskonsepsi siswa tentang materi reaksi redoks dengan sampel penelitian hanya satu ruang kelas $X$ di setiap sekolah di SMA Dharmawangsa Medan, SMA Negeri 1 Percut Sei Tuan, MAN 1 Medan, dan MAS PAB 2 Helvetia dan aktif pada Tahun Pelajaran 2020/2021. Adapun pertanyaan-pertanyaan tersebut adalah:

Tabel 6. Item Pertanyaan dalam Penelitian Hasil Penelitian Identifikasi Miskonsepsi

Penelitian ini menggunakan

\begin{tabular}{|c|c|c|c|c|c|}
\hline \multirow[t]{2}{*}{ Sub-Konsep } & \multicolumn{4}{|c|}{$\begin{array}{c}\text { Nomor Pertanyaan } \\
\text { dan Tingkat Kognitif }\end{array}$} & \multirow[t]{2}{*}{$\begin{array}{l}\text { Total } \\
\text { Item }\end{array}$} \\
\hline & $\bar{C} 1$ & $\mathrm{C} 2$ & C3 & $\mathrm{C} 4$ & \\
\hline $\begin{array}{l}\text { Reaksi redoks } \\
\text { berdasarkan } \\
\text { perubahan } \\
\text { bilangan oksidasi }\end{array}$ & & & & $\begin{array}{l}10, \\
11\end{array}$ & 2 item \\
\hline $\begin{array}{l}\text { Bilangan oksidasi } \\
\text { unsur dalam } \\
\text { senyawa atau ion }\end{array}$ & & 15 & 16 & & 2 item \\
\hline $\begin{array}{l}\text { Bilangan oksidasi } \\
\text { unsur dalam ion } \\
\text { poliatomik }\end{array}$ & 18 & 19 & & & 2 item \\
\hline $\begin{array}{l}\text { Oksidator dan } \\
\text { reduktor } \\
\text { reaksi }\end{array}$ & & 23 & 24 & & 2 item \\
\hline $\begin{array}{l}\text { Konsep } \\
\text { autoredoks }\end{array}$ & 26 & & & 30 & 2 item \\
\hline
\end{tabular}


instrumen tes dengan jumlah 10 (sepuluh) soal yang meliputi 5 (lima) sub-konsep pembelajaran pada materi Reaksi Redoks. Pemahaman siswa dibagi menjadi empat kategori yang berbeda untuk mengetahui kemampuan masing-masing siswa. Kategori tersebut terdiri dari Benar (SC), Benar Sebagian (PC), Miskonsepsi (SM), dan Tidak Memahami (NU). Berdasarkan hasil keseluruhan jawaban tes siswa menunjukkan bahwa terdapat beberapa siswa yang mengalami miskonsepsi pada setiap butir soal. Persentase miskonsepsi yang dialami siswa berbeda-beda pada setiap item dan subkonsep. Hasil pemahaman siswa pada setiap butir soal berdasarkan tes dapat dilihat pada Tabel 7.

Tabel 7. Persentase Miskonsepsi Siswa

\begin{tabular}{|c|c|c|}
\hline Sub-Konsep & $\begin{array}{c}\text { Nomor } \\
\text { Pertanyaan }\end{array}$ & $\begin{array}{c}\text { Rata-rata } \\
\text { Miskonsepsi }\end{array}$ \\
\hline $\begin{array}{ll}\text { Reaksi } & \text { redoks }\end{array}$ & 1 & $54,36 \%$ \\
\hline $\begin{array}{l}\text { berdasarkan } \\
\text { perubahan bilangan } \\
\text { oksidasi }\end{array}$ & 2 & \\
\hline Bilangan oksidasi & 3 & $65,18 \%$ \\
\hline $\begin{array}{l}\text { unsur dalam senyawa } \\
\text { atau ion }\end{array}$ & 4 & \\
\hline Bilangan oksidasi & 5 & $60,56 \%$ \\
\hline $\begin{array}{l}\text { unsur dalam ion } \\
\text { poliatomik }\end{array}$ & 6 & \\
\hline Oksidator dan & 7 & $54,09 \%$ \\
\hline reduktor dalam reaksi & 8 & \\
\hline Konsep autoredoks & $\begin{array}{c}9 \\
10\end{array}$ & $69,98 \%$ \\
\hline
\end{tabular}

Analisis miskonsepsi siswa pada masingmasing sub-konsep materi reaksi redoks akan dibahas sebagai berikut:

- Reaksi Redoks Berdasarkan Perubahan Bilangan Oksidasi

Rata-rata persentase miskonsepsi pada sub-konsep ini adalah 54,36\% yang termasuk kriteria miskonsepsi sedang. Miskonsepsi siswa yang ditemukan pada subkonsep ini diperoleh dari jawaban butir soal nomor 1 dan 2.

Miskonsepsi pertama yang dialami siswa dalam menentukan reaksi reduksi di bawah ini:

$$
2 \mathrm{KClO}_{3}(\mathrm{~s}) \rightarrow 2 \mathrm{KCl}_{(\mathrm{s})}+3 \mathrm{O}_{2}(\mathrm{~g})
$$

Reaksi reduksi terjadi pada atom $\mathrm{Cl}$ dalam $\mathrm{KClO}_{3}$ menjadi $\mathrm{KCl}$ karena bilangan oksidasi atom $\mathrm{Cl}$ dalam $\mathrm{KClO}_{3}$ adalah +5 dan bilangan oksidasi atom $\mathrm{Cl}$ dalam $\mathrm{KCl}$ adalah -1 sehingga terjadi reaksi reduksi (bilangan oksidasi menurun). Namun, $56,96 \%$ siswa mengalami miskonsepsi dengan anggapan bahwa reaksi reduksi terjadi pada atom $\mathrm{O}$ dalam $\mathrm{KClO}_{3}$ menjadi $\mathrm{O}_{2}$ karena bilangan oksidasi atom $\mathrm{O}$ dalam $\mathrm{KClO}_{3}$ adalah +3 dan bilangan oksidasi $O$ dalam $\mathrm{O}_{2}$ adalah +2 . Siswa masih belum mampu membedakan definisi oksidasi dan reduksi berdasarkan perubahan bilangan oksidasi. Pertanyaan dan jawaban soal nomor 1 adalah sebagai berikut:

01. Pada reaksi pemanasan $\mathrm{KClO}_{3}$ terjadi:

$$
2 \mathrm{KClO}_{3(\mathrm{~s})} \rightarrow 2 \mathrm{KCl}_{(\mathrm{s})}+3 \mathrm{O}_{2}(\mathrm{~g})
$$

Reaksi reduksi terjadi pada ..

A. Atom $\mathrm{Cl}$ pada $\mathrm{KClO}_{3}$ menjadi $\mathrm{KCl} * *$

B. Atom $\mathrm{Cl}$ pada $\mathrm{KCl}$ menjadi $\mathrm{KClO}_{3}$

C. Atom $\mathrm{K}$ pada $\mathrm{KClO}_{3}$ menjadi $\mathrm{KCl}$

D. Atom $\mathrm{O}$ pada $\mathrm{KClO}_{3}$ menjadi $\mathrm{O}_{2}$

E. Atom $\mathrm{O}$ pada $\mathrm{KClO}_{3}$ menjadi $\mathrm{KCl}$

Alasan:

A. Bilangan oksidasi atom $K$ pada $\mathrm{KClO}_{3}$ adalah +1 dan pada $\mathrm{KCl}$ adalah +1 sehingga tidak terjadi perubahan bilangan oksidasi

B. Bilangan oksidasi atom $O$ pada $\mathrm{KClO}_{3}$ adalah +3 dan pada $\mathrm{O}_{2}$ adalah +2 sehingga terjadi peristiwa reduksi

C. Bilangan oksidasi atom $O$ pada $\mathrm{KClO}_{3}$ adalah -6 dan pada $\mathrm{O}_{2}$ adalah 0 sehingga terjadi peristiwa reduksi

D. Bilangan oksidasi atom $\mathrm{Cl}$ pada $\mathrm{KClO}_{3}$ adalah +1 dan pada $\mathrm{KCl}$ adalah +1 sehingga tidak terjadi perubahan bilangan oksidasi

E. Bilangan oksidasi atom $\mathrm{Cl}$ pada $\mathrm{KClO}_{3}$ adalah +5 dan pada $\mathrm{KCl}$ adalah -1 sehingga terjadi peristiwa reduksi $* *$ 
Tingkat Keyakinan:

\begin{tabular}{|c|c|c|c|c|c|}
\hline 1 & 2 & 3 & 4 & 5 & 6 \\
\hline $\begin{array}{l}\text { Hanya } \\
\text { menebak }\end{array}$ & $\begin{array}{l}\text { Sangat } \\
\text { tidak } \\
\text { percaya } \\
\text { diri }\end{array}$ & $\begin{array}{l}\text { Tidak } \\
\text { percaya } \\
\text { diri }\end{array}$ & $\begin{array}{l}\text { Percaya } \\
\text { diri }\end{array}$ & $\begin{array}{l}\text { Sangat } \\
\text { percaya } \\
\text { diri }\end{array}$ & $\begin{array}{l}\text { Mutlak } \\
\text { percaya } \\
\text { diri }\end{array}$ \\
\hline
\end{tabular}

** jawaban yang benar

Miskonsepsi kedua yang dialami siswa dalam menentukan perubahan bilangan oksidasi sebanyak enam satuan. Pada pilihan jawaban dari (A) sampai (E), komponen yang mengalami perubahan bilangan oksidasi sebanyak enam satuan adalah $\mathrm{ClO}_{3}{ }^{-}$(aq) $\rightarrow$ $\mathrm{Cl}^{-}$(aq) karena bilangan oksidasi atom $\mathrm{Cl}$ dari +5 menjadi -1 sehingga dapat dikatakan mengalami perubahan bilangan oksidasi sebesar enam satuan. Tetapi, 51,77\% siswa mengalami miskonsepsi dengan anggapan bahwa jawaban benar ialah $\mathrm{SO}_{4}{ }^{2-}{ }_{\text {(aq) }} \rightarrow \mathrm{SO}_{2}$ (aq) karena atom $\mathrm{S}$ pada $\mathrm{SO}_{4}{ }^{2-}$ (aq) memiliki bilangan oksidasi $=+6$. Siswa berasumsi bahwa pilihan jawaban mana yang memiliki bilangan oksidasi sebanyak enam satuan, sedangkan pertanyaannya adalah pilihan jawaban mana yang memiliki perubahan bilangan oksidasi sebanyak enam satuan.

- Bilangan Oksidasi Unsur dalam Senyawa Atau Ion

Rata-rata persentase miskonsepsi pada sub-konsep ini adalah $65,18 \%$ yang termasuk kriteria miskonsepsi tinggi. Miskonsepsi siswa yang ditemukan pada subkonsep ini diperoleh dari jawaban butir soal nomor 3 dan 4 .

Miskonsepsi pertama yang dialami siswa dalam menentukan bilangan oksidasi $N=-3$ antara pilihan jawaban (A) sampai (E). Pada pilihan jawabannya, jawaban yang benar adalah $\mathrm{NH}_{3}$ karena atom $\mathrm{N}$ memiliki bilangan oksidasi -3 dan atom $H$ memiliki bilangan oksidasi +1 . Namun $60,08 \%$ siswa mengalami miskonsepsi dengan anggapan bahwa alasan atom $N$ memiliki bilangan oksidasi -3 karena memang semua atom $N$ mempunyai bilangan oksidasi -3 . Hal ini kurang tepat dan menimbulkan miskonsepsi siswa tentang ketepatan jawaban yang ditanyakan.

Selain itu, siswa juga mengalami miskonsepsi pada penentuan rumus atom karbon dan bilangan oksidasi karbon pada kalsium karbonat $\left(\mathrm{CaCO}_{3}\right)$. Atom karbon memiliki rumus $C$ dengan bilangan oksidasi $C=+4$. Namun siswa mengalami miskonsepsi dalam menentukan rumus atom karbon, siswa menjawab bahwa rumus atom karbon adalah $\mathrm{Ca}$, seharusnya rumus atom $\mathrm{Ca}$ untuk atom kalsium.

- Bilangan Oksidasi Unsur dalam Ion Poliatomik

Rata-rata persentase miskonsepsi pada sub-konsep ini adalah $60,56 \%$ yang termasuk kriteria miskonsepsi sedang. Miskonsepsi siswa yang ditemukan pada subkonsep ini diperoleh dari jawaban butir soal nomor 5 dan 6 .

Miskonsepsi pertama yang dialami siswa dalam menentukan ion poliatomik yang memiliki bilangan oksidasi +5 pada logam transisinya antara opsi jawaban (A) sampai (E). Jawaban yang benar adalah ion poliatomik yang memiliki bilangan oksidasi atom $\mathrm{Sb}=+5$ adalah $\mathrm{SbO}_{4}{ }^{3-}$ karena bilangan oksidasi ion/senyawa poliatomik = jumlah muatan ion/senyawa yang dimilikinya tersebut. Tetapi, $65,83 \%$ siswa mengalami miskonsepsi dengan anggapan bahwa bilangan oksidasi ion/senyawa poliatomik selalu bertanda positif/negatif. Itulah salah satu penyebab miskonsepsi siswa tentang ketepatan jawaban yang ditanyakan.

Miskonsepsi lain yang ditemukan dalam menentukan bilangan oksidasi pada logam transisi yang dicetak tebal pada senyawa poliatomik yang terdapat pada pilihan jawaban (A) sampai (E). Ion poliatomik adalah:

$$
\mathrm{NH}_{4}{ }^{+}, \mathrm{SO}_{4}{ }^{2-}, \mathrm{MnO}_{4}{ }^{-}, \mathrm{Fe}^{3+}
$$

Jawaban yang benar adalah atom $N$ pada $\mathrm{NH}_{4}{ }^{+}$memiliki bilangan oksidasi -3 , atom $S$ pada $\mathrm{SO}_{4}{ }^{2-}$ memiliki bilangan oksidasi +6 , atom $\mathrm{Mn}$ pada $\mathrm{MnO}_{4}{ }^{-}$memiliki bilangan oksidasi +7 , dan ion $\mathrm{Fe}^{3+}$ memiliki bilangan oksidasi +3 karena bilangan oksidasi ion/senyawa poliatomik $=$ jumlah 
muatan ion/senyawa yang dimilikinya tersebut. Tetapi, 55,29\% siswa memiliki miskonsepsi dengan anggapan bahwa ion $\mathrm{NH}_{4}{ }^{+}$memiliki bilangan oksidasi -4 , atom $S$ pada $\mathrm{SO}_{4}{ }^{2-}$ memiliki bilangan oksidasi +8 , atom $\mathrm{Mn}$ pada $\mathrm{MnO}_{4}{ }^{-}$memiliki bilangan oksidasi +8 , dan ion $\mathrm{Fe}^{3+}$ memiliki bilangan oksidasi +3 yang menunjukkan bahwa siswa belum dapat menentukan bilangan oksidasi dari ion dan senyawa poliatomik.

- Oksidator dan reduktor dalam reaksi

Rata-rata persentase miskonsepsi pada sub-konsep ini adalah 54,09\% yang termasuk kriteria miskonsepsi sedang. Miskonsepsi siswa yang ditemukan pada subkonsep ini diperoleh dari jawaban butir soal nomor 7 dan 8 .

Miskonsepsi pertama yang dialami siswa dalam menentukan oksidator dari reaksi di bawah ini:

$$
\mathrm{MnO}_{2}+4 \mathrm{HCl} \rightarrow \mathrm{MnCl}_{2}+2 \mathrm{H}_{2} \mathrm{O}+\mathrm{Cl}_{2}
$$

Oksidator dalam reaksi tersebut ditunjukkan oleh senyawa $\mathrm{MnO}_{2}$ karena atom $\mathrm{Mn}$ pada $\mathrm{MnO}_{2}$ yang memiliki bilangan oksidasi +4 mengalami reduksi dengan atom $M n$ pada $\mathrm{MnCl}$ yang memiliki bilangan oksidasi +2 , sedangkan reduktor ditunjukkan oleh senyawa $\mathrm{HCl}$ karena atom $\mathrm{Cl}$ pada $\mathrm{HCl}$ mengalami oksidasi dengan atom $\mathrm{Cl}$ pada $\mathrm{Cl}_{2}$ dengan perubahan bilangan oksidasi dari -1 menjadi 0 . Namun, $47,01 \%$ siswa mengalami miskonsepsi dengan menganggap bahwa oksidator adalah senyawa $\mathrm{HCl}$. Siswa masih belum mampu membedakan antara oksidator dan reduktor dalam reaksi redoks.

Begitu juga dengan soal miskonsepsi berikutnya, siswa harus menentukan oksidator dan reduktor dalam senyawa poliatomik sebagai berikut:

$$
\begin{gathered}
\mathrm{Cr}_{2} \mathrm{O}_{7}{ }^{2-}+6 \mathrm{Fe}^{2+}+14 \mathrm{H}^{+} \rightarrow \\
2 \mathrm{Cr}^{3+}+6 \mathrm{Fe}^{3+}+7 \mathrm{H}_{2} \mathrm{O}
\end{gathered}
$$

Oksidator dalam reaksi tersebut ditunjukkan oleh senyawa $\mathrm{Cr}_{2} \mathrm{O}_{7}{ }^{2-}$ karena atom $\mathrm{Cr}$ pada $\mathrm{Cr}_{2} \mathrm{O}_{7}{ }^{2-}$ mengalami reduksi dengan ion $\mathrm{Cr}^{3+}$ dengan perubahan bilangan oksidasi dari +6 menjadi +3 , sedangkan reduktor ditunjukkan oleh ion $\mathrm{Fe}^{2+}$ karena ion $\mathrm{Fe}^{2+}$ mengalami oksidasi dengan ion $\mathrm{Fe}^{3+}$ dengan perubahan bilangan oksidasi dari +2 menjadi +3 dengan alasan jawaban yang benar adalah reduktor adalah zat yang mengalami oksidasi. Pada butir soal ini, terjadi miskonsepsi sebesar $61,16 \%$ untuk menentukan contoh senyawa yang bertindak sebagai oksidator dan reduktor.

- Konsep Reaksi Autoredoks

Rata-rata persentase miskonsepsi pada sub-konsep ini adalah $69,98 \%$ yang termasuk kriteria miskonsepsi tinggi. Miskonsepsi siswa yang ditemukan pada subkonsep ini diperoleh dari jawaban butir soal nomor 9 dan 10.

Konsep reaksi autoredoks adalah bagian dari reaksi redoks di mana satu zat bertindak sebagai agen pereduksi dan pengoksidasi secara bersamaan. Pada soal ini terdapat $74,47 \%$ siswa mengalami miskonsepsi dengan anggapan bahwa konsep autoredoks adalah reaksi redoks di mana satu zat bertindak sebagai hasil dari reaksi reduksi dan oksidasi secara bersamaan. Miskonsepsi pada soal ini merupakan miskonsepsi tertinggi pada instrumen soal yang telah dibuat. Hal ini menunjukkan bahwa siswa belum mampu mendefinisikan konsep reaksi autoredoks. Pertanyaan dan jawabannya disajikan di bawah ini:

09. Apa yang dimaksud dengan reaksi autoredoks?

A. Reaksi redoks yang satu zatnya bertindak sebagai pereduksi dan pengoksidasi secara bersamaan**

B. Reaksi redoks yang satu zatnya bertindak sebagai hasil reaksi reduksi dan oksidasi secara bersamaan

C. Ukuran kemampuan suatu atom unsur untuk melepaskan atau menerima elektron dalam pembentukan senyawa

D. Zat di dalam reaksi redoks yang menyebabkan zat lain mengalami oksidasi

E. Zat di dalam reaksi redoks yang menyebabkan zat lain mengalami reduksi 
Alasan:

A. Konsep reaksi redoks sama dengan reaksi autoredoks

B. Konsep reaksi redoks berbeda dengan reaksi autoredoks**

C. Semua reaksi bisa membentuk reaksi autoredoks

D. Reaksi autoredoks disebut juga dengan reaksi konproporsionasi

E. Contoh reaksi autoredoks adalah $2 \mathrm{H}_{2} \mathrm{~S}+\mathrm{SO}_{2} \rightarrow 3 \mathrm{~S}+2 \mathrm{H}_{2} \mathrm{O}$

Tingkat Keyakinan:

\begin{tabular}{|c|c|c|c|c|c|}
\hline 1 & 2 & 3 & 4 & 5 & 6 \\
\hline $\begin{array}{l}\text { Hanya } \\
\text { menebak }\end{array}$ & $\begin{array}{l}\text { Sangat } \\
\text { tidak } \\
\text { percaya } \\
\text { diri }\end{array}$ & $\begin{array}{l}\text { Tidak } \\
\text { percaya } \\
\text { diri }\end{array}$ & $\begin{array}{l}\text { Percaya } \\
\text { diri }\end{array}$ & $\begin{array}{l}\text { Sangat } \\
\text { percaya } \\
\text { diri }\end{array}$ & $\begin{array}{l}\text { Mutlak } \\
\text { percaya } \\
\text { diri }\end{array}$ \\
\hline
\end{tabular}

** jawaban yang benar

Miskonsepsi lain ditemukan pada penentuan zat klorin yang bertindak sebagai reduktor dan oksidator secara bersamaan dalam reaksi autoredoks di bawah ini:

$$
\begin{gathered}
\mathrm{Cl}_{2}(\mathrm{~g})+2 \mathrm{KOH}_{(\mathrm{aq})} \rightarrow \\
\mathrm{KCl}_{(\mathrm{aq})}+\mathrm{KClO}_{(\mathrm{aq})}+\mathrm{H}_{2} \mathrm{O}_{(\mathrm{l})}
\end{gathered}
$$

Senyawa $\mathrm{Cl}_{2}$ bertindak sebagai reduktor dan oksidator secara bersamaan. Senyawa $\mathrm{Cl}_{2}$ mengalami reduksi dengan atom $C$ pada $\mathrm{KCl}$ dengan perubahan bilangan oksidasi dari 0 menjadi -1 dan senyawa $\mathrm{Cl}_{2}$ juga mengalami oksidasi dengan atom $\mathrm{Cl}$ pada dengan $\mathrm{KClO}$ dengan perubahan bilangan oksidasi dari 0 menjadi +1 . Tetapi, $65,50 \%$ siswa mengalami miskonsepsi bahwa atom kalium, oksigen, dan halogen tidak mengalami oksidasi atau reduksi, padahal semua senyawa berperan dalam reaksi autoredoks. Hal ini merupakan salah satu hal yang menimbulkan miskonsepsi siswa tentang ketepatan jawaban yang ditanyakan.

\section{Penyebab Miskonsepsi Siswa}

Dalam tes objektif Uji Instrumen Tiga Tingkat, siswa yang mampu menjawab dengan benar belum tentu memahami konsep, begitu pula siswa yang tidak dapat menjawab dengan benar belum tentu tidak memahami konsep. Berdasarkan analisis validator, instrumen penelitian ini masih memiliki kelemahan pada kalimat dan pilihan jawaban, selain itu terdapat siswa yang bingung saat mengisi jawaban pada tingkat kepercayaan diri dalam menjawab pertanyaan, maka penelitian ini disarankan untuk dikembangkan dengan menggunakan Tes Instrumen Empat Tingkat dan perlu diketahui alasan jawaban yang mereka pilih apakah benar atau salah.

Siswa mengerjakan angket penyebab miskonsepsi dalam pembelajaran reaksi redoks setelah mereka menjawab soal-soal Tes Instrumen Tiga Tingkat dengan Indeks Kepastian Respon (CRI). Hasil angket penyebab miskonsepsi siswa dalam pembelajaran reaksi redoks didapatkan persentase penyebab miskonsepsi tertinggi terdapat pada aspek materi, kemudian aspek sumber belajar, dan aspek guru. Agar penyebab miskonsepsi siswa yang bersumber dari Patil dkk. (2019) dapat dibuktikan, bahwa penyebab miskonsepsi juga disebabkan dari buku/bahan referensi, bahasa guru, keluarga, kelompok sebaya siswa, keyakinan budaya, media, dan keyakinan pribadi siswa karena siswa diajar oleh guru yang berbeda, metode yang berbeda, dan sumber belajar yang berbeda dalam mempelajari reaksi redoks di sekolah masing-masing.

\section{KESIMPULAN}

Berdasarkan hasil penelitian yang telah dilakukan, dapat disimpulkan bahwa:

Analisis dari proses belajar mengajar kimia di sekolah menggunakan kurikulum 2013 sebagai pedoman belajar mengajar, berbagai buku ajar dan metode pengajaran, sehingga peneliti mengembangkan indikator, kisi-kisi pertanyaan, instruksi kerja soal, Tes Instrumen Tiga Tingkat dengan Indeks Kepastian Respons (CRI), kunci jawaban, pedoman penilaian, dan angket penyebab miskonsepsi siswa pada penelitian. Data diperoleh dari wawancara dengan guru di masing-masing sekolah. 
Terdapat 15 (lima belas) soal dari 30 (tiga puluh) soal yang telah memenuhi syarat dengan nilai baik sebagai hasil dari kategori kelayakan instrumen tes objektif untuk mendeteksi miskonsepsi dengan Uji Instrumen Tiga Tingkat dengan Indeks Kepastian Respon (CRI). Soal-soal tersebut memuat 5 (lima) sub-konsep dalam reaksi redoks.

Persentase miskonsepsi siswa pada materi reaksi redoks dengan sub-konsep reaksi redoks berdasarkan perubahan bilangan oksidasi $(54,36 \%)$, dalam subkonsep bilangan oksidasi unsur dalam suatu senyawa atau ion $(65,18 \%)$, dalam subkonsep bilangan oksidasi unsur dalam ion poliatomik $(60,56 \%)$, dalam sub-konsep oksidator dan reduktor dalam reaksi $(54,09 \%)$, dan miskonsepsi dalam subkonsep reaksi autoredoks $(69,98 \%)$ dengan rasio persentase miskonsepsi keseluruhan adalah sedang. Artinya, Uji Instrumen Tiga Tingkat dengan Indeks Kepastian Respon (CRI) pada ini memenuhi syarat untuk mengetahui miskonsepsi siswa di berbagai sekolah terpilih di Sumatera Utara.

Penyebab miskonsepsi siswa dalam pembelajaran reaksi redoks berasal dari aspek materi, guru, dan sumber belajar. Hal tersebut dikarenakan siswa mendapat pengajaran oleh guru, metode, dan sumber belajar yang berbeda dalam pengajaran konsep reaksi redoks.

\section{DAFTAR PUSTAKA}

Anshory, A.F., Muntholib\&Kusumaningrum, I.K. (2016). Identifikasi kesulitan siswa dalam menyelesaikan soal-soal reaksi redoks berdasarkan perubahan bilangan oksidasi menggunakan analisis langkah penyelesaian soal. Prosiding Seminar Nasional Kimia dan Pembelajarannya (p. 119 - 122). Malang: FMIPA Universitas Negeri Malang

Dhindsa, H.S. \& Treagust, D.F. (2009).
Conceptual Understanding of Bruneian Tertiary Students: Chemical Bonding and Structure. Brunei International Journal of Science \& Mathematic Education. 1(1) : 33 - 51

Gani, A., Safitri, R., \& Mahyana, M. (2017). Improving the visual-spatial intelligence and results of learning of juniour high school students' with multiple intelligences-based students worksheet learning on lens materials. Jurnal Pendidikan IPA Indonesia, 6(1), 16-22. https://doi.org/10.15294 /jpii.v6i1.9594

Hazari, A. (2009). Misconceptions in Chemistry. In Misconceptions in Chemistry.https://doi.org/10.1007/978 $-3-540-70989-3$

Mahardika, R. (2014). Identifikasi Miskonsepsi Siswa Menggunakan Certainty of Response Index (CRI) dan Wawancara Diagnosis pada Konsep Sel. Jakarta: Universitas Islam Negeri Syarif Hidayatullah

Masykuri, M., Afifa, F. N., \& Ashadi. (2019). Students' misconceptions on basic concept of redox reaction. AIP Conference Proceedings, 2194 (December 2019). https://doi.org/10. $1063 / 1.5139794$

National Research Institute for Chemical Technology, (2010). Training Manual for Secondary School Chemistry Teachers and Technologists Zaria. Author

Nurlela, Mawardi, \& Kurniati, T. (2017). Kajian Miskonsepsi Siswa Melalui Tes Multiple Choice Menggunakan Certainty Of Response Index (Cri) Pada Materi Reaksi Reduksi Oksidasi Kelas X MIPA SMAN 1 Pontianak. Ar Razi Jurnal Ilmiah. 5(2), 225 238

Nurrohmah, E.S., Susilaningsih, E., \& Nuswowati, M. (2018). Instrument 
Design Diagnostic Test Three-Tier Multiple Choice Redox Material with Redox Diagnostic Test Software (RDT). Journal of Innovative Science Education, 7(2), 190 - 199

Salirawati, D. 2010. Pengembangan Model Instrumen Pendeteksi Miskonsepsi Kimia Pada Peserta Didik SMA. Disertasi Doktor. Program Pascasarjana Universitas Negeri Yogyakarta. Yogyakarta

Siswaningsih, W., Nahadi, N., \& Chandratika, V. (2020). Profile of Misconception in Senior High School Students on the Concept of Acid-Base Strength. https://doi.org/10.4108/eai. 12-10-2019.2296380

Patil, S. J., Chavan, R. L., \& Khandagale, V. S. (2019). Identification of Misconceptions in Science: Tools, Techniques \& Skills for Teachers. Aarhat Multidisciplinary International Education Research Journal (AMIERJ), 8(2), 466-472

Pinker, S. (2003). The blank state: Modern Denial of Human Nature. New York: Harper

Yuberti dan Antomi Siregar. 2017. Pengantar Metodolologi Penelitian Pendidikan Matematika Dan Sains, Bandar Lampung: CV. Anugrah Utama Raharja

Wulandari, P. I., Mulyani, B., \& Utami, B. (2019). Identifikasi Miskonsepsi Siswa Menggunakan Three-Tier Multiple Choice pada Materi Konsep Redoks Kelas X MIPA SMA Batik 1 Surakarta. Jurnal Pendidikan Kimia, 8(2), 207.https://doi.org/10.20961/ jpkim.v8i2.26766 